MIECZYSŁAW MARKOWSKI

\title{
JERZY WOLNY
}

Wysportowana sylwetka Jerzego Wolnego sprawia wrażenie, że jest on jeszcze młodzieńcem. Tymczasem ma on już 75 lat. Urodził się bowiem 2 listopada 1921 rok» w Rogoźniku, polożonym w Zagłębiu Dąbrowskim blisko Piekar Śląskich. Przyszedł na świat jako trzeci z kolei syn w rodzinie Stanisława i Jadwigi liczącej siedmioro dzieci. Trudne warunki poznał już we wczesnym dzieciństwie. Dzięki temu nabrał jednak niebywałego hartu ducha, pozwalającego mu stawiać czoło późniejszym przeciwnościom życiowym, które dla niego rozpoczęly się wcześnie. Do szkoły podstawowej uczęszczał w rodzinnej wsi, z którą do dnia dzisiejszego jest bardzo związany. W 1934 roku zacząl się uczyć w Państwowym Gimnazjum im. Jana III Sobieskiego w Piekarach Śląskich. Musiał więc codziennie pokonywać trasę aż sześciu kilometrów, najpierw pieszo, a później rowerem. Naukę na poziomie średnim przerwala mu druga wojna światowa. W 1939 roku miał za sobą pierwszą klasę Liceum Humanistycznego. W latach wojny kilkunastoletni Jerzy musiał ciężko pracować fizycznie w zakładach hutniczych i zarabiać na życie. Świadectwo dojrzałości uzyskał dopiero w 1945 roku w Tarnowskich Górach. Poznawszy smak robotniczego życia i zdobywszy wyksztalcenie średnie jako dwudziestoczteroletni mlodzieniec podjąl przemyślaną i dojrzałą decyzję o wstąpieniu do Wyższego Seminarium Duchownego. Najpierw było to seminarium diecezji katowickiej, a później częstochowskiej w Krakowie.

W dawnej stolicy Królestwa Polskiego, gdzie każdy kamień pamięta cząstkę jego historii, wypadło Jerzemu Wolnemu rozpocząć nowy etap życia. Zdobywając wiedzę wymaganą od kandydatów do stanu duchownego w latach 1945-1950 na Wydziale Teologii Uniwersytetu Jagiellońskiego, wnet dał świadectwo swoim zainteresowaniom historycznym. Już w 1946 roku zetknął się z ks. prof. drem Tadeuszem Glemmą, który w tym czasie prowadził wykłady i seminarium $\mathrm{z}$ historii Kościoła na Wydziale 
Teologii Uniwersytetu Jagiellońskiego. U tego znanego historyka Kościoła w Polsce zdobył pierwsze i zarazem solidne wykształcenie w zakresie historii Kościola. W tym czasie był także uczestnikiem prowadzonego przez ks. bpa prof. dra Michała Godlewskiego seminarium z historii Kościoła powszechnego. Na podstawie zdanych egzaminów oraz napisanej pod kierunkiem ks. prof. dra Tadeusza Glemmy pracy magisterskiej pt.: „Dzieje kościelne parafii Siemonia w Polsce przedrozbiorowej” Jerzy Wolny uzyskał w 1950 roku stopień magistra teologii. W tym samym roku otrzymał święcenia kaplańskie i zostal skierowany do pracy duszpasterskiej. Trwała ona od 1950 do 1954 roku. W czasie jej pełnienia poznal z bliska biedę ludzką, na którą okazał się bardzo wraźliwy. Mimo że praca duszpasterska absorbowala jego energię, pielęgnował wytrwale swoje zainteresowania historyczne i dzięki rekomendacji ks. prof. Glemmy zostal skierowany na dalsze studia uniwersyteckie z historii Kościoła.

Po likwidacji Wydziału Teologii na Uniwersytecie Jagiellońskim ośrodkiem studiów wyższych z zakresu historii Kościola stał się w tym czasie Katolicki Uniwersytet Lubelski. Na początku roku akademickiego 1954/55 Jerzy Wolny zjawił się w Lublinie, by kontynuować studia uniwersyteckie w sekcji historycznej Wydziału Teologii. Za swego głównego mistrza obrał ks. prof. dra Mieczysława Żywczyńskiego, który wykładal i prowadzil seminarium z zakresu historii Kościoła w średniowieczu i nowożytności. Pod jego też kierunkiem napisal w 1957 roku pracę licencjacką pt.: „Niedzielna suma w Polsce średniowiecznej”. Ponadto uczęszczał na wykłady i seminarium ks. prof. dra Mariana Rechowicza $z$ zakresu historii teologii i kultury w Polsce średniowiecznej. O ile pomorski uczony, ks. prof. Tadeusz Glemma, na Wydziale Teologii Uniwersytetu Jagiellońskiego ukształtował Jerzego Wolnego jako historyka Kościola, o tyle wspomniani profesorowie lubelscy skłonili go do zajęcia się historią Kościoła, teologii i kultury w Polsce w wiekach średnich. Z uniwersyteckiego środowiska lubelskiego wyszedł więc rokujący duże nadzieje mediewista z dobrą wiedzą, zwłaszcza z zakresu znajomości życia religijnego i kultury w średniowiecznej Polsce.

Mając stopnie naukowe magistra i licencjata teologii i posiadając dobre wykształcenie w zakresie życia religijnego i kultury w Polsce średniowiecznej, Jerzy Wolny przybyl ponownie do Krakowa, gdzie w Częstochowskim Seminarium Duchownym w 1957 roku zaczął wykładać historię Kościoła powszechnego i w Polsce. Niezależnie od prowadzonych wykładów pogłębial zdobytą uprzednio wiedzę i rozwijał swoje zainteresowania. Wielkie tradycje naukowe miasta oraz Biblioteka Jagiellońska ze swoim ogromnym zbiorem średniowiecznych kodeksów rękopiśmiennych umożliwiły młodemu mediewiście dalszą pracę naukową. Przy ślęczeniu nad niejednokrotnie wyblakłymi i trudno czytelnymi skrótami paleograficz- 
nymi zniszczonych średniowiecznych rękopisów miałem szczęście poznać Jerzego Wolnego, który już wtedy miał dobrze określony kierunek badań naukowych. Koncentrowaly się one na zbiorach kazań średniowiecznych. Ich ukoronowaniem była napisana pod kierunkiem ks. prof. Mieczysława Żywczyńskiego rozprawa doktorska pt.: „,Laciński zbiór kazań Peregryna z Opola i ich związek z tzw. Kazaniami gnieźnieńskimi". Obrona pracy odbyła się na Katolickim Uniwersytecie Lubelskim 26 czerwca 1961 roku, a promocja dnia następnego. Już samo podjęcie się opracowania rozproszonego w setkach rękopisów bibliotek europejskich zbioru kazań Peregryna z Opola wymagało dużego poświęcenia. Nie lada koncepcją naukową był pomysł ich bliższego porównania $\mathrm{z}$ Kazaniami gnieźnieńskimi, Niekwestionowanym i trwałym dorobkiem naukowym jego rozprawy doktorskiej było ustalenie związku między tymi dwoma zbiorami kazań i stwierdzenie, że dwa polskie kazania ,gnieźnieńskie" są przekladem analogicznych kazań lacińskich dominikanina, Peregryna z Opola. To ustalenie posiadało doniosłe znaczenie w zalążkowych badaniach nad dziejami średniowiecznego kaznodziejstwa w Polsce. Należy przy tym podkreślić, że Jerzy Wolny, idąc drogą wytyczoną przez Aleksandra Brücknera, który bodajże pierwszy docenil znaczenie kazań dla kultury i języka, wyszedł w swoich badaniach daleko poza kaznodziejstwo. Jego kapitalny wniosek posiadał także wielką wagę dla badań w zakresie historii i kształtowania się polskiego języka literackiego. Dzięki tym ustaleniom naukowym Jerzy Wolny zyskał znakomitą renomę naukową w polskim świecie mediewistycznym. Szkoda, że z jego rozprawy doktorskiej ukazały się tylko niektóre fragmenty opublikowane w pierwszym tomie Średniowiecza (por. 3.). Paweł Kocikowski, recenzując tę publikację w „Pamiętniku Literackim", stwierdzil m.in.: „Zebrany i przedstawiony w niej materiał dowodowy przyda się bezspornie nauce polskiej i znajdzie wielostronne zastosowanie. Autor rozprawy jest świetnie przygotowany właśnie do badań źródłowych, wobec czego można żywić uzasadnioną nadzieję, że jeszcze niejednokrotnie da znać o sobie w zaniedbanej dziedzinie badań mediewistycznych" (s. 309-310). Zainteresowania naukowe Jerzego Wolnego koncentrowały się nadal na średniowiecznym kaznodziejstwie w Polsce. Jest znamienne, że nie stał się on gabinetowym uczonym, lecz w pracy opieral się ciągle na źródlach, zwłaszcza rękopiśmiennych. Zdobywszy niepodważalny autorytet naukowy w kraju, mógł teraz pomyśleć o wyprawie na mało zbadane $w$ tej dziedzinie i rozległe szlaki europejskie. Zrealizowanie tego zamysłu w czasach panoszenia się komunizmu nie było latwe, co więcej, wydawało się urojeniem czy nawet mrzonką.

Uzyskawszy urlop naukowy od ówczesnego Ordynariusza diecezji częstochowskiej i poparcie prof. K. Wyki oraz doc. J. Woronczaka z Instytutu Badań Literackich Polskiej Akademii Nauk, Jerzy Wolny otrzymał 
od ówczesnych władz państwowych zezwolenie na wyjazd za granicę i w 1963 roku wyjechał do Paryża. Pobyt za granicą zapewniło mu otrzymane z puli Katolickiego Uniwersytetu Lubelskiego stypendium naukowe, które było przeznaczone w zasadzie na badania nad wyszukaniem średniowiecznych zbiorów kazań autorstwa Peregryna z Opola, kaznodziei o sławie europejskiej. Roczny pobyt w Paryżu wykorzystał Jerzy Wolny na dalsze pogłębienie swojej wiedzy. W tym celu zapisał się na Faculté des Lettres et Sciences Humaines paryskiej Sorbony. W roku akademickim 1963/64 uczęszczał na seminarium profesora Michela Mollata, poświęcone badaniom zagadnieniu ubóstwa $w$ średniowieczu. Na tym seminarium w 1964 roku wygłosił wykład na temat: „Zagadnienie ubóstwa w kazaniach Peregryna z Opola”. W tym czasie uczestniczył także w seminarium, które prowadzil profesor Jacques le Goff w École Pratique des Hautes Études. Przebywając we Francji, Jerzy Wolny rozpoczął zakrojoną na wielką skalę kwerendę średniowiecznych zbiorów kazań, szczególnie ukierunkowaną na kazania Peregryna z Opola. W tym celu pojechal też do Szwajcarii, Włoch i Anglii. W czasie tych podróży naukowych przebadał okoio dwustu kedeksów rękopiśmiennych, zawierających kazania Peregryna $z$ Opola.

Nawiązawszy kontakt ze znanym mediewistą i dogmatykiem profesorem Michaelem Schmausem, uczniem Martina Grabmanna, twórcą i wieloletnim dyrektorem Martin Grabmann-Institut na Uniwersytecie w Monachium, Jerzy Wolny przy jego poparciu otrzymał roczne stypendium badawcze na okres od 1 grudnia 1964 do 30 listopada 1965 roku z ramienia Alexander von Humboldt-Stiftung. Zapisawszy się na Uniwersytet Monachijski, odbyl tym razem studia specjalizacyjne na Seminar für Lateiniche Philologie u światowej sławy filologa łaciny średniowiecznej i wielkiego znawcy kultury średniowiecza, prof. dra Bernarda Bischoffa. Regularne uczestnictwo $w$ prowadzonym przez niego wyższym kursie paleografii, na które to zajęcia trzeba było się solidnie przygotowywać, sprawiło, że Jerzy Wolny posiadł wielką bieglość w zakresie paleografii. Uczęszczanie na wykłady prof. Bischoffa poszerzyło jego znajomość historii kultury średniowiecznej. Dobrze zaopatrzona biblioteka Instytutu Marcina Grabmanna pozwoliła Jerzemu Wolnemu na korzystanie $z$ najnowszej fachowej literatury.

W czasie pobytu w Monachium zawarł on wiele znajomości i przyjaźni osobistych. Był m.in. wielokrotnym gościem ks. prałata $\mathbf{M}$. Schmausa $w$ jego prywatnej rezydencji w Gauting. Przebywając w Monachium, prowadził także intensywne poszukiwania archiwalne i mozolne badania rękopisów średniowiecznych. Dotyczyły one nie tylko kaznodziejskich zbiorów Peregryna $z$ Opola, lecz także średniowiecznych poloników w Bayerische Staatsbibliothek. Wyniki tych badań ukazały się w książ- 
kowej publikacji (por. nr 11). W jednym z kodeksów rękopiśmiennych wspomnianej biblioteki zidentyfikował nie znany traktat antypolski z okresu polemik polsko-krzyżackich (por. nr 8). Wspomnieć wypada także, że w Bibliotece Miejskiej w Colmar odnalazł nieznany wiersz o bitwie pod Grunwaldem. We wrześniu 1965 roku Jerzy Wolny wyjechał do Austrii na miesięczne badania średniowiecznych rękopisów, zawierających zbiór kazań śląskiego dominikanina, Peregryna. Rozpoczął je w bibliotekach w Salzburgu, a skończył w Wiedniu. W tym ostatnim mieście w Österreichische Nationalbibliothek odkrył pochodzący z 1417 roku komentarz Pawla z Worczyna do De anima Arystotelesa (por. nr 5). Odnalezienie tego dziela przyczyniło się znacznie do poznania dziejów filozofii w tym czasie na Uniwersytecie Krakowskim. Jak z tego widać, Jerzy Wolny dwuletniego pobytu za graniç̨ nie poświęcil wyłącznie na elitarne studia specjalizacyjne, dzięki którym stał się znakomitym fachowcem w zakresie paleografii, kultury i kaznodziejstwa wieków średnich. Rękopiśmienne materiały, które w tym czasie zebrał i które mają wielkie znaczenie nie tylko dla nauki polskiej, zostały do tej pory - niestety - opublikowane w stopniu zaledwie znikomym.

Po powrocie do kraju już 16 grudnia 1965 roku Jerzy Wolny wygłosił w Międzywydziałowym Zakładzie Historii Kultury w Średniowieczu na Katolickim Uniwersytecie Lubelskim wykład pt.: „Moje badania w bibliotekach zagranicznych". Wykład ten był zarazem sprawozdaniem z wykorzystania otrzymanego stypendium. Już na początku następnego roku kalendarzowego podjąl on ponownie zajęcia dydaktyczno-wychowawcze w Częstochowiskim Seminarium Duchownym w Krakowie, prowadząc równocześnie ożywioną działalność naukowo-popularyzatorską, której wyrazem było wygłoszenie szeregu ważnych referatów. Dnia 26 kwietnia 1966 roku w czasie zorganizowanej przez Polskie Towarzystwo Teologiczne w Krakowie sesji poświęconej tysiącleciu chrześcijaństwa w Polsce wygłosił wyklad na temat: „Udzial polskiej teologii średniowiecznej w pracy duszpasterskiej Kościoła w Polsce”. W czasie uroczystości milenijnych w Piotrkouie nygłosił 23 września tegoż roku referat pt.: „Z przeszłości kościelnej i kulturalnej Piotrkowa", a już 26 września na sesji poświęconej piśmiennictuu polskiemu w XV wieku, którą zorganizowal Instytut Badań Literackich Polskiej Akademii Nauk, miał odczyt pt.: „Exempla w kazaniach Perergyna z Opola i Mikołaja z Błonia". Gdy 5 stycznia 1971 roku został powołany na uspółpracownika Komisji Filologii Klasycznej przy Oddziale PAN w Krakowie, przygotowal referat naukowy pt.: „Polskie redakcje traktatu antyhusyckiego "Eloquenti viro"". $\mathrm{Na}$ kongresie teologów polskich, który odbył się w dniach od 21 do 23 listopada 1972 roku w Lublinie, nygłosil w sekcji historycznej prelekcje pt.: „Postulaty badawcze do opracowania historii nauczania religijnego w Polsce średniowiecznej”. Na 
sesji naukowej zorganizowanej w dniach 29-30 listopada tegoż roku pod patronatem ks. kardynała Karola Wojtyły i poświęconej dziejom Polski i Krakowa w XI wieku przedstawił wykład pt.: „Biskupi polscy w XI wieku".

W 1972 roku Jerzy Wolny prowadził wykłady także w Śląskim Seminarium Duchownym, które w tym czasie mieścilo się w Krakowie. W tymże roku został powołany na członka Rady Naukowej Instytutu Migracji Polonijnej Katolickiego Uniwersytetu Lubelskiego. Dnia 10 marca 1973 roku na sympozjum naukowym $\mathrm{z}$ okazji 750 -lecia istnienia prowincji polskiej zakonu dominikanów w Warszawie przedstawil referat pt.: „Społeczeństwo w świetle kazań Peregryna z Opola". W czasie uroczystości 600-lecia urodzin królowej Jadwigi w katedrze na Wawelu miał 17 lutego 1974 roku odczyt pt.: „Zagadnienie formacji duchowej królowej Jadwigi” (por. nr 22). Również w 1975 roku wygłosił szereg prelekcji, m.in. na uroczystościach z okazji 50-lecia diecezji częstochowskiej wygłosil wykład w katedrze częstochowskiej i w Będzinie, zaś 26 października miał wykład inauguracyjny na rozpoczęcie roku akademickiego w ośrodku duszpasterskim w parafii -Św. Tomasza w Sosnowcu. Przedstawił także referat na uroczystej akademii ku czci kardynala Adama Stefana Sapiehy dla uczczenia 25. rocznicy jego śmierci. Ponadto zorganizowal wystawę dla uczczenia 25. rocznicy śmierci biskupa Teodora Kubiny. Zajął się również organizacją Archiwum i Biblioteki Diecezjalnej w Częstochowie. Poza dydaktyką i aktywnością naukowo-popularyzatorską Jerzy Wolny rozpoczął też dzialalność pisarską i wydawniczą. Na szczególną uwagę zasługuje w tym czasie przygotowanie do druku zebranych w Monachium poloników, które wraz z podobnymi materiałami Zdzisława Kuksewicza i Mieczyslawa Markowskiego ukazały się w osobnej książce (por. nr 11). Należy podkreślić, że Jerzy Wolny jest miłośnikiem książek. Zawsze chętnie odwiedza księgarnie. Nie troszczy się przy tym wyłącznie o własny księgozbiór. Jego dziełem było teź zorganizowanie Biblioteki Częstochowskiego Seminarium Duchownego. Przeglądnięcie dotychczasowego księgozbioru, jego należyte uporządkowanie i udostępnienie studiującym klerykom, dzięki fachowo opracowanym katalogom, było połączone $\mathrm{z}$ czasochłonną i mozolną pracą. Będąc dyrektorem tej Biblioteki aż do jej przeniesienia do Częstochowy, wzbogacil ją nie tylko o cenne pozycje krajowe, lecz także o wartościowe książki zagraniczne. Mimo tych licznych i różnorodnych zajęć w tym okresie niezwykłej aktywności zdołal jeszcze przygotować rozprawę habilitacyjną.

Dzięki dobrej znajomości piśmiennictwa teologicznego, a zwłaszcza średniowiecznych zasobów kaznodziejskich Jerzy Wolny mógł opracować ogromną syntezę, którą przedstawił w 1975 roku w rozprawie habilitacyjnej pt.: „Kształtowanie programu nauczania religijnego i organizacji kaz- 
nodziejstwa w Połsce średniowiecznej". Aby dowiedzieć się o jej wartości naukowej, należy oddać głos wybitnym specjalistom, którzy ją oficjalnie oceniali. Ks. prof. dr Marian Rechowicz stwierdził m.in.: „Ks. dr Jerzy Wolny, profesor Wyższego Seminarium Duchownego Częstochowskiego jest znanym i cenionym badaczem w zakresie historii Kościola w średniowieczu. Liczne studia analityczne, a zwłaszcza jego badania nad twórczością kaznodziejską Peregryna z Opola prowadzone w kraju i za granicą, przygotowały go znakomicie do podjęcia trudnej syntezy będącej przedmiotem niniejszej oceny. Dysertację habilitacyjną [...] podzielił autor na trzy części. W pierwszej $z$ nich podejmuje ks. dr Wolny ambitny i nie opracowany problem pt. "Kształtowanie programu nauczania religijnego w Polsce średniowiecznej« (s. 20-158), w drugiej pt.: "Kształtowanie organizacji kaznodziejstwa w Polsce średniowiecznej« znajdujemy panoramę kaznodziejstwa polskiego $w$ jego procesie rozwojowym aż po w. XV włącznie (s. 160-285); część trzecią stanowi repertorium pomników nauczania i zbiorów kazań (s. 287-384)”. [...] „Podziwiać należy erudycję ks. dra Wolnego, który z ogromną pracowitością pozbierał rozrzucone po różnych bibliotekach egzemplarze wspomnianej literatury teologicznej". [...] „Ks. Wolny dając syntezę tego, co dotychczas zostało powiedziane, uzupełnił dawne badania pokazując zbiory kazań i nazwiska kaznodziejów dotychczas nieznanych. Zebrany materiał uporządkował w sposób samodzielny”. [...] ,,Szacunek dla erudycji autora budzi jego znajomość ustawodawstwa synodalnego i orientacja w zakresie podręczników kaznodziejskich oraz wykresów osobowych”. [...] „Praca ks. dra Jerzego Wolnego jest nie tylko owocem wysiłku wielu lat, ale także jest prawdziwą panoramą polskiego dorobku w zakresie nauczania religijnego i kaznodziejstwa w wiekach średnich". Drugim recenzentem rozprawy habilitacyjnej Jerzego Wolnego był ks. prof. dr hab. Bolesław Kumor, który m.in. zauważył: „Podstawa źródłowa rozprawy habilitacyjnej ks. J. Wolnego jest imponująca. Liczba kodeksów średniowiecznych, objętych kwerendą autorską, obejmuje bardzo liczne rękopisy; dość wspomnieć, że sam wykaz bibliotek, przechowujących te kodeksy, wymienia 120 instytucji przeważnie zagranicznych". [...] ,Wielojęzyczna literatura przeđmiotu, w której autor świetnie się orientuje, wskazuje na wielkie bogactwo warsztatu naukowego ks. Wolnego". [...] „Bardzo wartościowa jest część 3. rozprawy, omawiająca piśmiennictwo $\mathrm{z}$ zakresu nauczania religijnego i kolekcje autorów polskich $\mathrm{z}$ okresu średniowiecza. Jest to wspaniałe repertorium polskiego piśmiennictwa religijnego i kaznodziejskiego $\mathrm{z}$ okresu średniowiecza. Ks. Wolny zestawił $w$ niej 28 autorów, wykazy ich zachowanych dzieł wraz $\mathrm{z}$ pełną dokumentacją bibliograficzną. Ta iście benedyktyńska praca będzie służyła $z$ powodzeniem polskim mediewistom $w$ pracy naukowej jako dobry przewodnik po zbiorach rękopiśmiennych". Nadal wciąż 
aktualny pozostaje postulat wypowiedziany w 1975 roku przez ks. prof. Bolesława Kumora: „Trzeba tylko życzyć, by praca w całości mogła się ukazać jak najwcześniej". Trzecim recenzentem rozprawy habilitacyjnej Jerzego Wolnego był prof. dr Jerzy Zathey, który m.in. powiedział: „Przedłożona mi do oceny praca ks. dra Jerzego Wolnego jest niewątpliwie imponującym owocem wieloletnich gruntownych studiów". [...] „Najbardziej efektywną częścią pracy ks. dra Wolnego, częścią, do której będzie się najczęściej zaglądało jest cz. III pt.: „Piśmiennictwo z zakresu nauczania religijnego i kolekcje kazań autorów polskich $\mathrm{z}$ okresu średniowiecza". Jest to starannie i $\mathrm{z}$ wielkim nakladem pracy zestawione repertorium dziel autorów polskich ze wskazaniem rękopisów, w których dzieła te znajdują się". [...] „Przy porównaniu dotychczasowego stanu badań z wynikami długoletniej starannej kwerendy ks. dra Wolnego powstaje uspokajające przeświadczenie, że oto wreszcie powstała baza dla nowej próby syntezy, bliższej temu, co kryją w sobie źródla. Wydobycie nowych szczególów, przeprowadzenie potrzebnych identyfikacji, poprawienie kursujących nieścisłych danych daje wystarczające podstawy do kreślenia obrazu dziejów kultury, tym razem bliższego prawdy. Nie tylko sięganie do źródel na niespotykaną dotąd $w$ badaniach polskiej średniowiecznej teologii skalę pozwala wysoko oceniać wysiłki autora. Wyniki jego umacnia stale przeprowadzana konfrontacja danych wydobytych ze źródeł $\mathrm{z}$ dotychczasowym ujęciem literatury krajowej i zagranicznej. Częste wnioski wyciągane z badanych rękopisów nadają poszczególnym częściom pracy charakter nowości badawczej". Na podstawie tych chlubnych ocen rozprawy habilitacyjnej Jerzy Wolny otrzymał 29 listopada 1975 roku stopień doktora habilitowanego.

Wykladający nadal w Wyższym Częstochowskim Seminarium Duchownym ks. dr hab. Jerzy Wolny, decyzją Rady Naukowej Papieskiego Wydziału Teologicznego w Krakowie z dnia 25 czerwca 1976 roku został powołany na stanowisko docenta historii Kościoła na tej uczelni. Tę decyzję zatwierdziła Sacra Congregatio pro Institutione Catholica w Rzymie dnia 28 marca 1977 roku. Na tej podstawie wielki kanclerz papieskiego Wydziału Teologicznego w Krakowie, Karol kard. Wojtyła, mianował 12 maja tegoż roku Jerzego Wolnego docentem na tym Wydziale. Niezależnie od tego Jerzy Wolny otrzymal też etat docenta na Wydziale Filozofii Katolickiego Uniwersytetu Lubelskiego, gdzie w latach 1977-1981 prowadził wykłady $z$ historii kultury starożytnej i średniowiecznej oraz z zakresu dziejów uniwersytetów w wiekach średnich. Dnia 10 maja 1978 roku zostal powolany na członka korespondenta Towarzystwa Naukowego Katolickiego Uniwersytetu Lubelskiego. Po habilitacji kontynuowal swoją rozległą działalność dydaktyczno-wychowawczą. Był świetnym wykładowcą $\mathrm{i}$ wymagającym a nawet surowym wychowawcą. Po rezygnacji $z$ etatu 
docenta na Wydziale Filozofii Katolickiego Uniwersytetu Lubelskiego od 1982 roku aż do przejścia na emeryturę wykladal najpierw jako docent, a potem jako profesor na Wydziale Historii Kościoła Papieskiej Akademii Teologicznej w Krakowie. Z ogromną szkodą dla mediewistyki w Polsce, czyniąc zadość życzeniu Karola kard. Wojtyły, podjąl się opracowania pontyfikatu metropolity krakowskiego księcia Adama Stefana Sapiehy.

Zarówno praca dydaktyczna, jak i działalność badawczo-naukowa Jerzego Wolnego sprawiły, że na Papieskiej Akademii Teologicznej w Krakowie wystąpiono $\mathrm{z}$ wnioskiem o przyznanie mu tytułu profesora nadzwyczajnego. Pohablitacyjny dorobek naukowy oceniał wybitny historyk krakowski, prof. dr hab. Jerzy Wyrozumski, pisząc m.in.: „Wszystkie one [prace naukowe Jerzego Wolnego] świadczą o dobrym przygotowaniu ich Autora i o jego gotowości zabierania głosu publicznie i w druku na tematy historyczne. Czyni to nie tylko w sposób wysoce kompetentny, ale i interesujący, co uważam za istotny element kwalifikacji profesorskich". [...] „W konkluzji pragnę stwierdzić, że dorobek naukowy ks. doc. Jerzego Wolnego, tak bogaty i różnorodny, przedstawia zarazem wysokie naukowe walory. W swojej wärstwie mediewistycznej jest on bardzo spójny i zarówno poziomem naukowym, jak też zakresem problemowym, odpowiada w pełni wymogom nowoczesnej mediewistyki i wzbogaca poważnie naszą wiedzę o życiu duchowym i kulturze Polski średniowiecznej. W warstwie dotyczącej czasów nowożytnych jest on epizodyczny, częściowo okolicznościowy, a najbardziej zwarty $w$ odniesieniu do regionu, tj. do obszaru diecezji częstochowskiej. W warstwie dwudziestowiecznej, widzianej przez pryzmat wielkiej postaci Adama Stefana Sapiehy, jest on, przynajmniej do lat 1939-1951 fundamentalny $\mathrm{z}$ punktu widzenia dziejów Kościoła polskiego". Prof. dr hab. Brygida Kürbis z Uniwersytetu Adama Mickiewicza $w$ Poznaniu $w$ swojej opinii $w$ sprawie nadania tytułu profesora nadzwyczajnego Jerzemu Wolnemu podkreśliła m.in.: „Twórczość naukową ks. docenta dra Jerzego Wolnego cechuje erudycyjność w najlepszym i od wielu generacji sprawdzonym sensie, tj. akuratnej pracy nad zapisem źródłowym, na którego najpierw odszukanie i sprawdzenie zużyty czas nigdy nie uważa się za stracony. Zwięzly i rzeczowy wykład dostrzeżonych kwestii otwiera korzystającemu $z$ jego prac dobrą perspektywę poznawczą. Sa to wszystko cechy o dużym walorze dydaktycznym, a w dyscyplinie, jaką jest historia Kościoła, zarówno dawnego jak i wspólczesnego, cechy szczególnie poszukiwane". Ks. prof. Bolesław Kumor, charakteryzując pohabilitacyjny dorobek naukowy Jerzego Wolnego, stwierdzal m.in.: „Prace naukowe ks. doc. dra Jerzego Wolnego po habilitacji (1975) obejmują zasadniczo 2 problemy badawcze: a) piśmiennictwo teologiczne, a nade wszystko literaturę kaznodziejską w Polsce średniowiecznej i b) pontyfikat i działalność księcia metropolity Adama Stefana kardynała Sapiehy, 
oraz c) popularyzację historii kościelnej w Polsce". [...] ,Trzeba stwierdzić, że ten kierunek prac naukowych [studia nad kodeksami rękopiśmiennymi] ks. doc. dra hab. J. Wolnego stanowi poważny wklad w rozwój polskich badań historycznych i stawia go $w$ rzędzie doświadczonych $\mathrm{i}$ znanych polskich mediewistów. W zakresie średniowiecznego kaznodziejstwa polskiego ks. Wolny należy niewątpliwie do czołówki". O drugim kierunku badawczym Jerzego Wolnego, który dotyczy różnorodnej działalności księcia arcybiskupa Adama Sapiehy, ks. prof. B. Kumor powiedział m.in.: „Wszystkie te artykuły i rozprawy posiadają rzetelną dokumentację, najczęściej archiwalną, przytaczają in extenso cały szereg dziesiątków nieznanych dotąd dokumentów i jeszcze większą liczbę publikowanych pierwszy raz w języku polskim. Bez żadnej przesady trzeba stwierdzić, że trzy wyżej wymienione opracowania posiadaja niesłychanie ważny walor dla dziejów Polski i Kościoła w Polsce, do których badacze będą musieli często zaglądać tak ze względu na przytoczone in corpore operis dokumenty, jak też i merytoryczną treść tych opracowań. Jest to niewątpliwie ważki wkład ks. J. Wolnego w poznanie dziejów Polski i Kościoła polskiego w latach 1925-1951. Trzeba i to podkreślić, że szereg problemów bardziej szczegółowych $z$ czasów II wojny światowej ks. Wolny podjąl pierwszy raz w polskiej historiografii". Już z przytoczonych krótkich fragmentów tych trzech bardzo pochlebnych opinii widać, że Jerzy Wolny jest znanym specjalistą nie tylko w zakresie mediewistyki, lecz także w dziedzinie rozległej znajomości życia i dzieła arcybiskupa-metropolity krakowskiego, Adama Stefana kardynała Sapiehy.

Po uzyskaniu w stosunkowo późnym czasie tytułu profesora nadzwyczajnego Jerzy Wolny bynajmniej nie zaniechał swojej ożywionej działalności, która poza wykonywanymi obowiązkami kapłańskimi i ulubionym sportem dotyczyła dydaktyki, szerokiej popularyzacji nauki i naukowej twórczości piśmienniczej. Jego wykłady w Papieskiej Akademii Teologicznej, a od 1957 roku w Częstochowskim Seminarium Duchownym a potem Sosnowieckim Seminarium Duchownym w Krakowie poświęcone były historii Kościoła powszechnego. W tych uczelniach prowadził te $\dot{z}$ seminaria naukowe, na których pod jego kierunkiem napisano szereg prac magisterskich. W Sosnowieckim Seminarium Duchownym zajął się znowu organizowaniem biblioteki naukowej. Jako referent występował trzy razy na Colloquia Mediaevalia w Olsztynie. W ramach Tygodni Kultury Katolickiej wygłaszał referaty m.in. w Krakowie, Częstochowie, Przemyślu. Na uwage zasługują też wygłoszone przez niego przemówienia i prelekcje okolicznościowe. Jego dzialalność popularyzatorska znalazła też odzwierciedlenie $w$ niektórych artykułach.

Glówne kierunki naukowych zainteresowań Jerzego Wolnego i jego wkład do nauki zostanie scharakteryzowany na podstawie jego publikacji. 
Biorąc rzecz najogólniej można powiedzieć, że osiągnięcia naukowe ks. prałata Jerzego Wolnego dotyczą dwóch dziedzin, tj. mediewistyki i krakowskiego Kościoła za pasterzowania księcia Adama Stefana kardynała Sapiehy.

W zakresie mediewistyki działalność piśmiennicza Jerzego Wolnego jest dosyć różnorodna. W niej dominują wszakże dzieje życia religijnego i kultury duchowej w średniowiecznej Polsce. Gdy rozpoczynał swoją działalność naukowo-badawczą, te dziedziny wiedzy były zbadane w niewielkim stopniu. Toteż zrozumiał on, że aby na tej niwie zrobić coś trwałego, należy najpierw zacząć poszukiwania podstaw źródłowych. Dlatego rozpoczął żmudne i czasochlonne poszukiwania rękopiśmienne najpierw w bibliotekach krajowych, zwłaszcza kościelnych, a potem i w zagranicznych. Wnikliwie i calościowo zinwentaryzował średniowieczne rękopisy teologiczne zachowane w Bibliotece Kapitulnej w Kielcach (por. 13). $\mathrm{Na}$ solidnej bazie rękopiśmiennej oparł też swoją rozprawę doktorską i pracę habilitacyjną, które ze względu na ogromną wagę naukową zasługują na szybkie opublikowanie. Badając kaznodziejstwo w polskim średniowieczu, doszedł do wniosku, że doniosłą wartość naukową posiada zbiór kazań niedzielnych i świątecznych Peregryna z Opola. Ponieważ zbiór ten zyskał w późnym średniowieczu wielką popularność nie tylko na Śląsku, lecz także w całej prawie Europie, Jerzy Wolny zrozumiał, że należy podjąć europejską kwerendę rękopiśmienną $w$ celu naukowego przedstawienia postaci Peregryna z Opola i ustalenia autentycznego zbioru jego kazań, określenia dokonanych $\mathrm{w}$ tych kazaniach przeróbek i zaprezentowania wplywu kazań Peregryna, zarówno w pierwotnej jak i w zmienionej postaci, w kręgach kultury europejskiej, zwłaszcza zaś polskiej. Wyniki badawcze i ustalenia dotyczące Peregryna z Opola, stały się już dzisiaj glówną podstawą badań dla zachodnich uczonych (np. przyznaje to Thomas Wünsch). Odkrycia cennych poloników przez Jerzego Wolnego w średniowiecznych kodeksach rękopiśmiennych bibliotek monachijskich pokazały, że polska średniowieczna myśl astronomiczna, filozoficzna i teologiczna nie miała znaczenia tylko lokalnego, lecz także spotkała się z żywym zainteresowaniem na kontynencie europejskim. Poza Peregrynem z Opola w szczególny sposób zafascynowała Jerzego Wolnego postać wielkiej królowej Jadwigi, która swoją glęboką formację duchową promieniowała za życia nie tylko na najbliższe otoczenie, lecz także wywarła niezatarty wplyw na kilka generacji magistrów, doktorów i profesorów Uniwersytetu Krakowskiego. Kultywowali oni jej tradycję duchową i wspominali ją w specjalnie odprawianych nabożeństwach żałobnych, w wypominkach mszalnych i w uroczystych wykładach wstępnych $\mathrm{z}$ okazji uzyskania stopni naukowych (por. m.in. nry 9, 22, 25). W mediewistycznym dorobku Jerzego Wolnego znajduje się wiele studiów o charakterze 
przyczynkarskim i prac drobniejszych (jak artykuły o wagantach w Polsce średniowiecznej), stanowiących owoc jego rozległych studiów kodykologicznych i kwerend źródłowych. Prace te obejmują w pierwszym rzędzie kaznodziejstwo średniowieczne, ale niektóre $\mathrm{z}$ nich wkraczają też na teren koncyliaryzmu, husytyzmu (np. w polskich rękopisach odkrył Floretus theologicus), filozofii, literatury, a nawet poezji. W mediewistycznym dorobku naukowym ks. Wolnego znajdują się też znakomite syntezy dotyczące dziejów katechezy i kaznodziejstwa w Polsce średniowiecznej (por. nry 19 i 21), w których zaproponowal on nową, przekonywającą periodyzacje oświaty kościelnej. Jak z tej krótkiej charakterystyki wynika, Jerzy Wolny dzięki dobrze opanowanej metodzie badań naukowych trzymania się źródeł rękopiśmiennych radzi sobie doskonale na każdym etapie badań w zakresie mediewistyki. Jego osiągnięcia naukowe $w$ tej dziedzinie są tak wielkie, że stawiają go one w czolówce polskich mediewistów.

$O$ ile prowadząc badania nad średniowieczem, pozostawał pod szczególnym urokiem wybitnego śląskiego kaznodziei Peregryna z Opola i świątobliwej królowej Jadwigi, o tyle $w$ jego naukowych zainteresowaniach dotyczących czasów niedawno minionych olśniła go postać krakowskiego arcybiskupa-metropolity, księcia Adama Stefana Sapiehy. Temu poprzednikowi papieża-Polaka, Jana Pawła II, poświęcil on sporo czasu i wiele pracy. I w tym wypadku przypadło Jerzemu Wolnemu podjąć badania od podstaw. Trzeba je było zacząc od rozległej kwerendy osobowej i materialowej. W pierwszym przypadku musiał on znaleźć grono kompetentnych osób, które znały lub mogłyby coś rzetelnego napisać na temat różnorodnej działalności księcia Adama Sapiehy. Nadesłane materialy opracował pod względem redakcyjnym, przy czym sam napisal jedną trzecią artykułów, liczących lącznie ponad trzysta stron. Dwa grube tomy obejmującej blisko 1500 stron Księgi Sapieżyńskiej (por. nry 49 i 67) stały się wielkim wydarzeniem naukowym lat osiemdziesiątych obecnego stulecia. Podejmując się tego trudnego zadania na wyraźne życzenie ówczesnego metropolity krakowskiego, Karola kard. Wojtyły, Jerzy Wolny pokazal, że jest znakomitym historykiem także nowszych czasów. Przedstawiając wspaniały okres czterdziestoletniej działalności księcia-duszpasterza Adama Stefana Sapiehy, zgromadzil po raz pierwszy dokumenty o unikatowym znaczeniu, wydobył wiele cennych materialów biograficznych, na podstawie korespondencji i prywatnych notatek kompetentnie wyświetlił $\mathrm{i}$ interesująco przedstawil jego mądre decyzje i roztropne przedsięwzięcia w okresie pracy na Stolicy Apostolskiej w latach 1906-1911, a zwlaszcza w czasie niełatwych rządów na stolicy biskupiej św. Stanisława w Krakowie w latach 1911-1951, szczególnie zaś w czasie okupacji i po drugiej wojnie światowej. Zredagowana i częściowo napisana przez Jerzego Wolnego Ksiega Sapieżynska jest bardzo wartościowym dziełem naukowym 
i posiada doniosłe znaczenie dla bliższego poznania dziejów Kościoła krakowskiego w tym okresie.

Sumując należy stwierdzić, że do swoich wspaniałych osiągnięć naukowych ks. prałat Jerzy Wolny doszedł dzięki niezwykłej pracowitości, umiejętności wyrażania wyważonych ocen i dojrzałych sądów. Zbliżająca się 75 . rocznica urodzin Jerzego Wolnego będzie niewątpliwie dobrą okazją do przypomnienia, jego już ukończonych prac, jednocześnie szybko upływający czas wzywa do możliwie rychłego i calkowitego zakończenia tych dawno już rozpoczętych i do wydania ich drukiem. W wielkim stopniu mogą to ułatwić nadchodzące jubileusze Jagiellońskiej Fundacji Wydziału Teologii i odnowy Uniwersytetu Krakowskiego.

\section{SPIS PUBLIKACJI JERZEGO WOLNEGO}

\section{7}

1. „Pragnienie widzenia Hostii”. Przyczynek do historii kultu Najśw. Sakramentu $w$ Polsce na przelomie XIII-XIV w., ,Częstochowskie Wiadomości Diecezjalne" 31, nr 6 (1957), s. 253-255.

\section{8}

2. Śp. ks. Tadeusz Glemma (1895-1958), „Częstochowskie Wiadomości Diecezjalne" 32, nr 8 (1958), s. 290-292.

\section{1}

3. Laciński zbiór kazañ Peregryna z Opola i ich zwiqzek z tzw. "Kazanianiami gnieźnieńskimi«. W: Średniowiecze. Studia o kulturze, t. 1, Warszawa 1961, s. 171-238.

Rec.: P. Kocikowski, „Pamiętnik Literacki” 59 (1968), s. 366-370.

\section{4}

4. La pauvreté et les pauvres dans les sermons de Peregrinus d'Opole, „Cahiers de Recherches sur la Pauvreté et les Pauvres" 2 (1963-1964). 


\section{6}

5. Informacja o komentarzu do "De anima" Pawla z Worczyna z rękopisu Biblioteki Narodowej $w$ Wiedniu, „Materiały i Studia Zakładu Historii Filozofii Starożytnej i Średniowiecznej" VI (1966), s. 92-95.

6. Udzial polskiej teologii średniowiecznej w pracy duszpasterskiej Kościola w Polsce, „Ruch Biblijny i Liturgiczny” 19, z. 2 (1966), s. 74-82.

7. Uzupelnienie do katalogu dziel Pawla z Worczyna, ,Materiały i Studia Zakładu Historii Filozofii Starożytnej i Sredniowiecznej” 6 (1966), s. 96.

\section{8}

8. Nieznany traktat przeciw pismom Pawla Wlodkowica, „Studia Mediewistyczne" 9 (1968), s. 293-306. [W tym traktacie na stronie 304 znajduje się edycja wiersza: Antonius Slesita, Bellum Ladislai regis Maioris ac Minoris Poloniae peractum inter Brutenos et fratres Teutonicos].

9. Królowa Jadwiga w oczach wspólczesnych, „Tygodnik Powszechny” 23, nr 30 (1969).

10. Materialy do historii wagantów w Polsce średniowiecznej, „Biuletyn Biblioteki Jagiellońskiej" 19 (1969), s. 73-89.

Rec.: P. Spunar, „Ceskaslovenský Časopis Historycký” 4/5 (1970).

Rec.: B. Kürbis, „Studia Źródłoznawcze” 17 (1972), s. 249.

11. Polonica $w$ średniowiecznych rękopisach bibliotek monachijskich. Wroclaw 1969, 208 stron (wraz z M. Markowskim i Z. Kuksewiczem).

Rec.: B. Kürbis, „Studia Źródłoznawcze” 15 (1971), s. 249.

12. Studenci Uniwersytetu Krakowskiego $w X V$ wieku $z$ terenu diecezji czestochowskiej, ,Częstochowskie Wiadomości Diecezjalne” 43, nr 3-6 (1969), s. 95-108.

1971

13. Inventaire des manuscrits théologiques médiévaux de la Bibliothèque du Chapitre à Kielce, „Mediaevalia Philosophica Polonorum" 16 (1971), s. 43-85.

14. Kubina Teodor Filip. Biskup czestochowski. W: Polski slownik biograficzny, t. 16, Wroclaw 1971, s. 28-30. 
15. Postulaty badawcze do opracowania historii nauczania religijnego $w$ Polsce średniowiecznej. W : Teologia a antropologia. Kongres teologów polskich, 21-23 IX 1971, Kraków [1971], s. 324-329.

1972

16. Sylwetka biskupa we wczesnym średniowieczu, „Tygodnik Powszechny” 27, nr 19 (1972), s. 1-2.

1973

17. Biskupi polscy w XI wieku, „Tygodnik Powszechny” 28, nr 1 (1973), s. 4-5.

18. Tematy nauczania religijnego w pierwszym okresie chrystianizacji Polski, „Częstochowskie Studia Teologiczne” 1 (1973), s. 191-212.

1974

19. Kaznodziejstwo. W: Dzieje teologii katolickiej w Polsce. Tom 1: Średniowiecze, Lublin 1974, s. 275-308.

20. Maciej z Szydlowa. W: Polski slownik biograficzny, t. 19, Wrocław 1974, s. 37-38.

21. Z dziejów katechezy. W: Dzieje teologii katolickiej w Polsce. Tom 1: Średniowiecze, Lublin 1974, s. 151-209.

22. Zagadnienie formacji duchowej królowej Jadwigi. Wykład w czasie uroczystości 600-lecia urodzin Bł. Królowej Jadwigi w Bazylice na Wawelu 17 lutego 1974 r., „Notificationes e Curia Metropolitana Cracoviensi" 3-4 (1974), s. 63-71.

23. Zagadnienie formacji duchowej królowej Jadwigi, „Duszpasterz Polski za Granicą" 25, nr 3/112 (1974), s. 311-318. Por. 22.

24. Biskup Pelczar. W: Materialy z sesji naukowej poświęconej życiu i dzialalności slugi Bożego J.S. Pelczara, Kraków 21 marca 1974, redakcja: B. Przybyszewski, K. M. Kasperkiewicz, Rzym 1975, s. 53-54.

25. Królowa Jadwiga w tradycji kaznodziejskiej XV wieku, „Analecta Cracoviensia" 7 (1975), s. 15-90 (wraz z R. Zawadzkim).

26. Michal z Czeszewa. W: Polski slownik biograficzny, t. 20, Wrocław 1975 , s. $622-623$.

27. Panorama przeszlości kościelnej terytorium diecezji czesstochowskiej, geneza jej powstania $i$ pierwotny model organizacyjny. Wykład na sesji 
z okazji 50-lecia istnienia diecezji częstochowskiej na Jasnej Górze, „Częstochowskie Wiadomości Diecezjalne” 49, nr 7-8 (1975), s. $175-184$.

28. Uwagi o kaznodziejstwie dominikańskim w Polsce średniowiecznej. W: Studia nad historiq dominikanów w Polsce, t. 1, Warszawa 1975, s. 543-552.

29. Mikolaj z Miliczyna. W: Polski slownik biograficzny, t. 21, Wrocław 1976, s. 126.

30. Mikolaj Wigandi z Krakowa. W: Polski slownik biograficzny, t. 21, Wrocław 1976, s. 117-120.

31. Tematy nauczania pierwszego biskupa czestochowskiego Teodora Kubiny, „Częstochowskie Wiadomości Diecezjalne” 50, nr 4-5 (1976), s. $105-111$.

32. Maurycy Rvačka i "Floretus theologicus" $w$ rękopisach Biblioteki Jagiellońskiej $i$ innych księgozbiorów, „Biuletyn Biblioteki Jagiellońskiej” 27 (1977), s. 5-20.

1978

33. Exempla z kazań niedzieinych Peregryna z Opola (edycja tekstów). W: Kultura elitarna a kultura masowa w Polsce późnego średniowiecza, pod redakcją B. Geremka, Wrocław 1978, s. 243-283.

1979

34. Biskup krakowski w perspektywie historycznej, „Tygodnik Powszechny” 33, nr 4 (1979), s. 1, 6.

35. Sesje historyczne $w$ okresie pasterzowania kardynala Karola Wojtyly. W: Karol Wojtyla jako biskup krakowski, pod redakcją T. Pieronka, Kraków 1979, s. 451-499.

36. Średniowieczne kazania o św. Stanislawie biskupie-meczenniku (tekst polski), ,Tygodnik Powszechny” 33, nr 19 (1979), s. 1, 4.

37. Krakowskie środowisko katedralne $w$ czasach Jana Dlugosza (1431-1480). W: Dlugossiana. Studia historyczne w piéćsetlecie śmierci Jana Dlugosza, Kraków 1980, s. 85-105. 
38. Pawel z Zatora. W: Polski slownik biograficzny, t. 25, Wrocław 1980, s. $401-403$.

39. Peregryn z Opola. W: Polski slownik biograficzny, t. 25, Wrocław 1980, s. 599-602.

40. Polnische Emigrantenseelsorge in Rheinland und Westfalen. W: Mit der Kirche auf dem Weg durch die Zeit. Freundesgabe zum 65. Geburtstag von Helmut Holzapfel, Würzburg 1980, s. 156-160.

41. Zagadnienie formacji duchowej królowej Jadwigi. W: Być czlowiekiem $i$ chrześcijaninem. Praca zbiorowa pod redakcją bpa B. Bejze W nurcie zagadnień soborowych, t. 12, Warszawa 1980, s. 171-178. Por. 22.

\section{1}

42. Grunwald - 15 lipca 1410. "Bogurodzica" $i$ chwala zwycięstwa, „Niedziela" XXIV, nr 8 (1981), s. 4-5.

43. Od odsieczy wiedeńskiej do powstania warszawskiego. Wykład na 300-lecie przybycia ss. wizytek do Krakowa, ,Tygodnik Powszechny" 35 , nr 50 (1981), s. 3.

44. Odsiecz wiedeńska, „Niedziela" XXIV, 22 (1981), s. 6.

45. Odsiecz wiedeńska”, „Niedziela” XXIV, 24 (1981), s. 5.

46. Odsiecz wiedeńska, „Niedziela” XXIV, 26 (1981), s. 5.

\section{2}

47. Adam Stefan Sapieha w Watykanie w latach 1906-1911. W: Ksiega Sapieżyńska. Tom 1: Archidiecezja krakowska za pasterzowania Adama Stefana Sapiehy, Kraków 1982, s. 55-167.

48. Kardynal Adam Stefan Sapieha $w$ slużbie Kościola i Narodu, „Niedziela" XXX, 6 (1982), s. 1, 4.

49. Ksiega Sapieżyńska. Tom 1: Archidiecezja krakowska za pasterzowania Adama Stefana Sapiehy. Praca zbiorowa pod redakcją J. Wolnego przy współpracy R. Zawadzkiego, Kraków 1982, 516 stron.

Rec.: T. Żychiewicz, „Tygodnik Powszechny” 39, nr 20 (1985).

Rec.: A. Biernacki, Krzyż - lukiem przymierza, „Przegląd Katolicki" 74 nr 31/32 (1986).

Rec.: S. Gawęda, „Chrześcijanin w Świecie” 189 (1989), s. 83-89.

50. Mlodość i pierwsze lata dzialalności Adama Stefana Sapiehy. W : Ksiega Sapieżyńska. Tom 1: Archidiecezja krakowska za pasterzowania Adama Stefana Sapiehy, Kraków 1982, s. 31-48.

51. Od Redakcji. W: Ksiega Sapieżyńska. Tom 1: Archidiecezja krakowska za pasterzowania Adama Stefana Sapiehy, Kraków 1982, s. 13-16. 
52. (Opis rękopisu BJ 418). W: Catalogus codicum manuscriptorum medii aevi Latinorum qui in Bibliotheca Jagellonica Cracoviae asservantur. Volumen II numeros continens inde a 332 usque ad 444, composuerunt M. Kowalczyk, M. Markowski, G. Zathey, M. Zwiercan, Wratislaviae 1982, s. 244-247.

53. „Prawda jest podwalinq stosunków między ludźmi...”, „Tygodnik Powszechny" 36, nr 30 (1982), s. 1, 4.

54. Więź metropolitalna archidiecezji krakowskiej z diecezja częstochowska w latach 1926-1951. W: Ksiega Sapieżynska. Tom 1 : Archidiecezja krakowska za pasterzowania Adama Stefana Sapiehy, Kraków 1982, s. 904-905.

55. Odsiecz wiedeniska, „Niedziela" XXV, 2 (1982), s. 6.

1983

56. Kazanie wygloszone w katedrze wawelskiej w czasie uroczystej Mszy św. dziękczynnej celebrowanej przez biskupa Jana Pietraszkę sufragana krakowskiego z okazji 300-lecia odsieczy wiedeńskiej 11 września 1983 roku, Kraków 1983, 18 stron.

1984

57. (Opis rękopisu BJ 529). W : Catalogus codicum manuscriptorum medii aevi Latinorum qui in Bibliotheca Jagellonica Cracoviae asservantur, Volumen III numeros continens inde a 445 usque ad 563, composuerunt M. Kowalczyk, A. Kozłowska, M. Markowski, S. Włodek, G. Zathey, M. Zwiercan, Wratislaviae 1984, s. 264-266.

58. Osobowość $i$ dziedzictwo blogoslawionej królowej Jadwigi. Wykład w katedrze wawelskiej podczas Mszy św. odprawionej przez biskupa Stanisława Smoleńskiego $\mathrm{z}$ okazji pielgrzymki młodzieży w rocznice 600-lecia koronacji błogosławionej królowej Jadwigi 14 października 1984, Kraków 1984, 16 stron.

59. Wstep do wspomnienia kard. Mario Nasalli Rocca di Corneliano: Ja sobie go dobrze przypominam..., ,Tygodnik Powszechny” 38, nr 14 (1984) s. 1.

1985

60. Czechy. Czesko-polskie kontakty religijne. W: Encyklopedia katolicka, t 3, Lublin 1985, kol. 803-804.

61. Elucidarium. W: Encyklopedia katolicka, t. 4, Lublin 1985, kol. 904-905 . 
62. Osobowość $i$ dziedzictwo blogoslawionej królowej Jadwigi. (Wykład w katedrze wawelskiej z okazji 600-lecia koronacji błogosławionej królowej Jadwigi w czasie pielgrzymki młodzieży), „Niedziela” XXXVIII, 14-15 (1985), s. 8-9.

\section{6}

63. Abp A. S. Sapieha o zadaniach episkopatu i biskupa. W: Ksiega Sapieżyńska. Tom 2: Dzialalność kościelna i narodowa Adama Stefana Sapiehy, Kraków 1986, s. 59-69.

64. Abp A. S. Sapieha $w$ obronie Narodu i Kościola polskiego podczas II wojny światowej. W: Księga Sapieżyńska. Tom 2: Dzialalność kościelna $i$ narodowa Adama Stefana Sapiehy. Kraków 1986, s. $203-472$.

65. Blogoslawiona królowa Jadwiga i kult świetych Cyryla i Metodego., W: Dialog Kościola i kultura. Tom 2: Materialy z VI $i$ VII Tygodnia kultury chrześcijańskiej w Krakowie 1985, Kraków 1986, s. 18-24.

66. Konflikt wawelski. W: Ksiega Sapieżynska. Tom 2: Dzialalność kościelna i narodowa Adama Stefana Sapiehy, Kraków 1986, s. 111-179.

67. Ksiega Sapieżyńska. Tom 2: Dzialalność kościelna i narodowa Adama Stefana Sapiehy, Praca zbiorowa pod redakcją ks. J. Wolnego przy współpracy R. Zawadzkiego, Kraków 1986, 920 stron.

68. Ostatnie lata dzialalności kościelnej A. S. Sapiehy. W : Ksiega Sapieżyńska. Tom 2: Dzialalność kościelna i narodowa Adama Stefana Sapiehy, Kraków 1986, s. 499-567.

\section{8}

69. Rodzina Jan. W: Polski slownik biograflczny, t. 31, Wroclaw 1988, s. $373-374$.

\section{9}

70. Zagadnienie formacji duchowej królowej Jadwigi. W: Dzielo Jadwigi $i$ Jagielly. W sześćsetlecie chrztu Litwy $i$ jej zwiqzków z Polska, wybór i opracowanie W. Biliński. Warszawa 1989, s. 115-119. Por. 22.

\section{0}

71. Kaznodziejstwo katedralne w Krakowie na tle środowiska (okres 1520 -1584). W: Cracovia litterarum. Kultura umyslowa Krakowa i Ma- 
lopolski $w$ dobie renesansu. Oddział Krakowski PAN, Kraków 1990, s. 285-318.

72. Rospond Stanislaw. W: Polski slownik biograficzny, t. 32, Wroclaw 1990, s. $124-126$.

73. Uwagi nad kaznodziejstwem uniwersyteckim w Krakowie w XV stuleciu.

W: Świety Jan Kanty - w sześćsetnq rocznice urodzin 1390-1990, Kraków 1991, s. 27-54.

74. Sapieha Adam Stefan (1867-1951). W: Polski slownik biograficzny, t. 34, Wrockaw 1993, s. 539-556.

1995

75. Adam Stefan. W: Dom Sapieżyński, oprac. E. Sapieha. Warszawa 1995, s. 579-612.

76. Cztery wizyty kardynala A. S. Sapiehy w Watykanie w latach 1946-1950. W: Adam Stefan Sapieha - mąż stanu i kaplan, Przemyśl 1995, s. 117-147.

77. Materialy do nauczania wiary w Polsce średniowiecznej. „Analecta Cracoviensia" 27 (1995), s. 653-659.

78. Z badań nad życiem i dzialalnościq biskupa krakowskiego Adama Stefana Sapiehy. W: Adam Stefan Sapieha - maż stanu $i$ kaplan, Przemyśl 1995, s. 29-33.

79. Z przeszlości życia kościelnego na terytorium obecnej diecezji sosnowieckiej. W: Sosnowieckie studia teologiczne, t. 2, Kraków, Sosnowiec 1995 , s. 9-21.

Prace w druku

80. Jakub z Fusignano. W: Encyklopedia katolicka.

81. Jan z Rochelle. W: Encyklopedia katolicka.

82. Jan ze Slupczy. W: Encyklopedia katolicka.

83. Jordan $z$ Quedlinburgu albo z Saksonii. W: Encyklopedia katolicka.

84. Wstęp. W: Peregrinus Opoliensis, Sermones de tempore et de sanctis (edycja polska, redakcja naukowa, przygotowanie do druku). 